Bojan Krstić ${ }^{1}$

University of Nis, Faculty of Economics

Milos Krstić ${ }^{2}$

Research Associate at the University of Nis,

Faculty of Science and Mathematics
ORIGINAL SCIENTIFIC ARTICLE doi:10.5937/ekonomika1601001K

Received: February 9, 2016

Accepted: March 1, 2016

\title{
THE APPLICATION OF THE MODEL OF INSTRUMENTAL RATIONALITY AND THE MODEL OF VALUE RATIONALITY IN THE ANALYSIS OF PERSONAL AND SOCIAL GOAL PREFERENCES ${ }^{3}$
}

\begin{abstract}
The main aim of the research is to determine whether the model of instrumental rationality or model of value rationality better explains the respondents' behaviour. In the research, we used the following statistical techniques: descriptive analysis, factor analysis and the one-factor analysis of variance with planned comparisons. The results of the descriptive analysis of the sample of students of the Faculty of Economics show that young people gravitate towards egoistic, selfish ends ("material standard", "friends", "social power", "independence", "enjoyment", "popularity", etc.). When it comes to personal and social goals of the respondents in the sample of the high school students from the Vocational School of Economics, the results of the descriptive analysis reveal the pupils willingness to give up their personal utility for the common good. The factor analysis of personal and social goals of high school students and university students indicates that the model of instrumental rationality better explains the respondents' behaviour than the model of value rationality. In accordance with the results, participants never honestly act for the welfare of others. Finally, the main results of the one-factor analysis of variance with planned comparisons confirmed the second hypothesis of the research according to the subjects that evaluated socioeconomic conditions of their families as "good" and "moderate" have higher levels of instrumental rationality.
\end{abstract}

Keywords: model of instrumental rationality, value rationality model, personal goals, social goals, factor analysis.

JEL classification: A10

\footnotetext{
${ }^{1}$ bojan.krstic@eknfak.ni.ac.rs

${ }^{2}$ krsticmilo3@gmail.com

${ }^{3}$ This paper was presented at 24th Cromar Congress on the Marketing Theory and Practice Building Bridges and Fostering Collaboration, Split, Croatia, 22-24 October 2015. The paper is part of the research project entitled "Improving the Competitiveness of Public and Private Sectors by Networking Competences in the European Integration Process of Serbia" Number 179066, financed by the Ministry of Education, Science and Technological Development of the Republic of Serbia.
} 


\title{
ПРИМЕНА МОДЕЛА ИНСТРУМЕНТАЛНЕ РАЦИОНАЛНОСТИ И МОДЕЛА ВРЕДНОСНЕ РАЦИОНАЛНОСТИ У АНАЛИЗИ ПРЕФЕРЕНЦИЈА ЛИЧНИХ И ДРУШТВЕНИХ ЦИЉЕВА
}

\begin{abstract}
Апстракт
Главни изиь истраживана је да се утврди да ли модел инструменталне или модел вриедносне рационалности боле објашюава понашане испитаника. У истраживану су коришћене стедеће статистичке технике: дескрипривна анализа, факторска анализа и једнофакторска анализа варијансе с планираним поређенима. Резултати дескриптивне анализа у узорку студената Економског факултета показују да млади највише теже егоистичким, себичним ицлевима ("материјални стандард", "пријатели”, “друштвена моћ”, “самосталност”, “уживане”, “популарност итд.). Када је реч о тичним и друштвеним изиьевима испитаника у узорку ђака Економске школе, резултати дескриптивне анализе откривају спремност ученика да се одрекну тичне користи зарад општег добра. Факторска анализа личних и друштвених ицлева ђака и студената указује да модел инструменталне рационалности боле објашнава понашаюе учесника истраживана од модела вредносне рационалности. У складу са резултатима, учесници истраживана никад на искрен начин не делују за добробит других. Коначно, резултати једнофакторске анализе варијансе поткреплују другу хипотезу истраживаюа, по којој, субјекти, који социоекономске стане своје породице оценују као “добро" и "осредюе, имају виши степен инструменталне рационалности.
\end{abstract}

Клучне речи: модел инструменталне рачионалности, модел вредносне рационалности, лични циилеви, друштвени циилеви, бакторска анализа.

\section{Introduction}

Models allow the available instruments to come to the essence of the object of the research. Models are used for the crystallization of ideas, isolation of the problem, definition of important phenomena, analysis of the environment and the determination of a causal link. Constructing the model is a creative act in which we must take into account the general regularly (investigated) phenomena, as well as their specific properties, because the model should not be too abstract or too detailed (Itzhak Gilboa et al., 2014).

To its widest extent, neoclassical economic theory corresponds with the model of instrumental rationality. The model of instrumental rationality is "inhabited" with economic actors whose activities are targeted and always rational. It is about perfectly rational actors who reason and act reasonably in all situations. As managers, they maximize profit. As consumers, they maximize their utility or, correspondingly, select the highest point on the indifference curve (Menkju, 2007). In the model of instrumental rationality, it is assumed that there is compliance between the internal values of actors. In this way, the problem of heterogeneity of personal objectives which complicates the formalization and implementation of the model is ignored. Moreover, this assumption allows ignoring 
the importance of the cultural context, thus avoiding possible contradictions between personal and social goals.

Scientists who do not belong to neoclassical economic theory claim that neoclassical economic theory pays a high "price" for isolation from researches, showing that individuals in the carefully constructed environment often exhibit behaviour that is inconsistent with the model of instrumental rationality. Ignoring the fact that it is not always possible to define the problem correctly in practice, formulating goals precisely and properly interpreting all available information resulted in broadening the gap between theoretical models and economic reality. Because of this, the critics of neoclassical economic theory proposed new approaches in which the model of instrumental rationality is expanded and explained. In one of them, the model in which the individual must choose a goal that is in line with the social values (value model of rationality) is applied. The actor faces the values that he alone does not define and that he passively observes and analyses.

In this paper, we analyse the personal and social goals with the intention to determine whether the model of instrumental or model of value rationality better explains the behaviour of human subjects. In the research of human behaviour (Inglehart, Schwartz, Fromm, Murray, Bilsky) we paid less attention to the possible separation of personal and social goals, and especially the systematic and parallel studies of both groups. In this paper, however, the distinction between personal and social goals was made.

\section{The Model of Instrumental Rationality}

In the model of instrumental rationality, rationality is defined as instrumental, when the actor's activity is directed towards the choice of means, which is the best way to achieve the goal (Shastiko, 1998). How to form a goal and what kind of context it is based on are the questions within the model of instrumental rationality which cannot be answered. The subject is perceived as a "box", and the "entrance" represents all data, while the "exit" represents the adopted solutions. What processes occur within the "box", from the standpoint of the model of instrumental rationality, is not of any importance, until the economic actors use the best means to achieve the set goals (Shastiko, 1998).

Instrumental rationality and the assumption of the exogenous impact of culture and institutions on the behaviour of individuals are determined by the existing possibilities of formalization of models (decision-making) and its checks. In order to solve the problem of formalization of model, when some of the facts (institutions, culture, etc.) that affect the behaviour of individuals remain invisible, the presumption is introduced, according to which only the observed variables are changed. In the case of the consumer, it is assumed that the budget constraint changes. Therefore changes in demand can be explained by changes in prices and income (Shastiko, 1998).

Suppose that the consumer chooses the quantity of goods corresponding to point A (Figure 1a). The choice of point A indicates rational behaviour, because the consumer (whose behaviour we observe) provides a greater flow of goods than the flow of goods at point $\mathrm{B}$. As the new line budget constraint (Figure 1b) contains a flow of goods in the point $B$ that is less than the flow of goods at point $A$, the choice the point $B$ is contrary to Schvery's definition (1997: 37) of rationality, according to which, "the actor never chooses 
alternative $\mathrm{B}$ if alternative $\mathrm{A}$ is available at the same time, which, according to him, is better than alternative B". On the basis of the observations above, we can see that the analysis of consumer behaviour is more complex when the changes to budgetary constraints are assumed, which will be neutralized only if the stability of goals of consumers and the systems of social values can be assumed (Shastiko, 1998). What is more, the fact that the system of goals of each customer has its own peculiarities should not be ignored.

\section{Figure 1 a) The rationality of consumer behaviour; b) The irrationality of consumer behaviour}
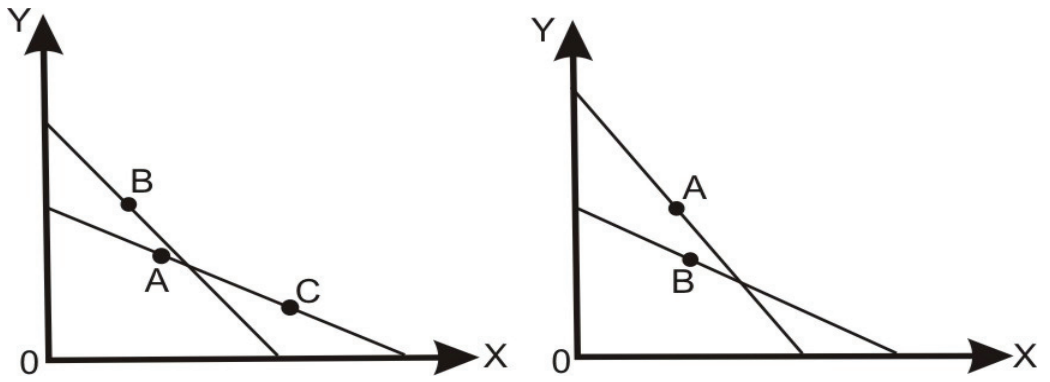

Source: Shastitko, A. (1998), "Models of Human Rational Economic Behavior”, Voprosy Economici, No. 5, p. 58.

As stated above, the model of instrumental rationality does not deal with the examination of the internal factors of rationality. In other words, it is assumed that there is compliance of internal goals of the individual. In this way, the problem of a multitude of "I" within man, which complicates the formalization, and the implementation of model-making is ignored. Moreover, this assumption allows ignoring the importance of the cultural context, thus avoiding possible contradiction between many "I" within man and the system of social values (Schvery, 1997).

\section{The Model of Value-Expressive Rationality}

In the model of value rationality, player chooses the goal aligned with the system of social values. (Simon, 1993). The process of choice depends on both the internal and social values that the actor adopts through the process of learning and socialization. In the process of socialization, actors adopt social values that they alone do not define (reducing corruption and crime, keeping traditions and customs, establishing greater trust between the authorities and the people, etc.) and learns to believe a priori in the honesty of others.

Social interactions function only when they are based on partial or complete confidence. Despite the limited knowledge and diminished intellectual capacity, the person expects other people to act in good faith and be consistent in all or some aspects of joint activities. However, a person who gives his trust reduces the level of instrumental rationality, and becomes vulnerable. Therefore, one may decide not to take that risk at all, but that is how one reduces the value or level of expressive rationality. 
Besides confidence, the level of expressive rationality or value depends on "cognitive dissonance" (Smelser and Swedbwrg, 1996). Cognitive dissonance is a mental condition in which a person experiences two or more incompatible cognitions (items of knowledge). These cognitions are an obstacle for the creation of psychological balance and comfort, while a man will do anything to escape this awkward situation. There are two basic ways of "liberation". The first consists from "preconceptions", i.e. from the purification of the previously processed information in order to create a "unique image" (Shastiko, 1998). Another way is to create one's own reality (Elster, 2000).

In the model of value rationality, many factors can lead the change of the original rational actors' goal. The change depends, among other things, on the choice of the means. The problem of the choice of the means is the result of the differences in their effectiveness. What is effective for achieving one goal need not be effective for the achievement of another goal. In the long run, "trust", "reciprocity" and "cooperation" that create conditions for the establishment of a Pareto optimal equilibrium (Shastiko, 1998).

\section{Research on the Structure of Preferences of Personal and Social Goals of High School Students and University Students}

Problems of this paper belong to the field of values and value orientations. If the goals (whether extremely personal or declared as social) are formulated in relatively general terms and involving the idea of stability and permanent orientation, then these are values for individuals or a group. Some well-known researchers of values - for example, Rokeach (Rokeach, 1973), Schwartz and Bilsky (Schwartz and Bilsky, 1990), Inglehart (Inglehart, 1977) - examined the value systems of individuals and groups through the shortest-named and generalized goals, regardless of the fact that they more often use terms of values and "guiding principles" rather than literally - life goals. All values probably do not have and may not be expressed as targets, especially if it is something already achieved, or if the separation of values-goals and values-means (instrumental values) is insisted on.

In previous research, less attention was paid to the disconnections of acceptance of social and personal goals, and especially to the systematic and parallel studying of both groups Researchers of values were more concerned with the other classifications of values, such as the terminal and instrumental (Rokeach, 1973), materialistic and post-materialist (Inglehart, 1977), and the personal and social aspects were mixed or it remained unclear to which reference frame the subject is directed. In their previous article, among other things, Rohan (Rohan, 2000) theoretically discussed the distinction of personal and social value systems, pointing out that insufficient attention was paid to this problem in previous works. However, although this author treats both of these systems as intrapsychic (inner), he understands social values somewhat differently than is the case in this paper. Rohan believes that social values are, above all, the perception of the value of other people. In other words, social values are what one expects that other people will do. Some other authors who have also made this distinction (Schwartz and Bilsky, 1987) saw social values as the values of the individual that he can achieve in the presence and with the help of others (e.g. personal safety). In this paper, unlike the 
previously mentioned ones, social goals pursued by respondents will be considered as objectives whose achievements are not tied exclusively to their benefit, but which also have significance for the whole society in which individuals live.

\subsection{Personal and Social Goals That are Covered by This Research}

Personal goals are an expression of the needs and desires of individuals. In the research of preferences of high school students and university students, personal goals are divided into the personal objectives of pro-individual orientation ("name", "friends", "social power", "actualization", "exciting life”, "safety”, "material standards", "knowledge”, "enjoyment", "independence", "popularity" and "healthy life") and personal objectives of pro-welfare orientation ("altruism", "achievement", "subordination", "diligence", "love", "social engagement"). Social objectives are based on the assumption that individuals will, to some extent, take into account the interests of other people and society as a whole. The list of social objectives includes: "a strong economy", "good interethnic relations", "the fight against crime and corruption", "strengthening defense forces", "humane relations", "environmental objectives", "preservation of tradition", "employment", "social equality", "the rule of law", "privatization of public enterprises", "democracy", "living standards", "development of science and technology", "social rights".

In designing and choosing the list of personal and social goals, we were guided by the following researches: "Explorations in Personality" (Murray, 1938), "Motivation and Personality" (Maslow, 1982), "A Healthy Society" (Fromm, 1980), "The Nature of Human Values" (Rokeach, 1973), “The Silent Revolution" (Inglehart, 1977), "Priorities and Behavior: Applying a Theory of Integrated Value Systems" (Schwartz, 1996) "Toward a Psychological Structure of Human Values" (Schwartz and Bilsky, 1987), "Toward a Psychological Structure of Human Values" (Schwartz and Bilsky, 1990), "The values of members of informal groups" (Vasović, 1988), "Preference structure of personal and social goals of the high school students" (Kuzmanović and Petrović, 2007). When it comes to choosing social goals, we have taken into account the numerous public opinion surveys (like: Mihajlović, S., Stojiljkobić, Z., Vuković Đ., Mojsilović, M. (2007). Survey of Serbian Public Opinion, Fall 2007. year, Beograd CESID) in which current social goals and interests were examined.

\subsection{Objectives and Research hypotheses}

The objects of the research are relatively generalized personal (life) goals and the individual's relation (level of acceptance and preference) to also relatively general social goals. Specifically, the research had several main research goals:

1. The degree of acceptance, or preferences among the offered personal and social goals.

2. Determining the structure of personal and social goals that individuals accept or do not accept.

3. Determining whether the model of instrumental or value rationality better explains the behaviour of the participants in the research.

We started from the following hypothesis:

1. The model of instrumental rationality explains the behaviour of real actors better than the models of value rationality. 
2. Respondents whose families live as good and moderate indicate high levels of instrumental rationality.

We created the hypothesis I on the basis of the research by Bora Kuzmanovic and Nebojša Petrović: "Preference Structure of Personal, and Social Goals of the HighSchoolers", which shows that respondents, on the one hand, mostly tend to friendship and love, and on the other hand, to independence, self-actualization, material and life standard (Kuzmanovic and Petrovic, 2007). In previous studies of the social styles preference, striving for power was at the very bottom by acceptance among the young people while striving for popularity obtained higher marks (Kuzmanovic and Petrovic, 2007).

In designing hypothesis II, we were guided by the research by Koposov et al.: "Alchohol Abuse in Russian delinquent adolescents". Koposov and colleagues noted, examining the influence of some of the families on the consumption of harmful goods (alcohol), that the irrational and socially unacceptable behaviour is associated with dysfunctional family, inadequate parental supervision and their indifference towards children (Koposov et al, 2005).

\subsection{The Method}

In a survey of the preferences of high school and college students, we used the following instruments: 1) the questionnaire, 2) survey, 3) model of instrumental rationality and 4) model of value rationality.

1) With the help of a questionnaire, we explored the socioeconomic situation of the family. In the questionnaire, we asked respondents about: gender, highest educational attainment of parents and the socio-economic situation of the family. The questionnaire was created on the basis of the research by Milana Ljubičić: "Psychopathology of Juvenal Delinquents: a Family and Social Influence" (Ljubičić, 2010).

2) With the help of surveys, we examined the presence and intensity of personal and social goals. In the survey, each of the objectives was presented to the respondents (i.e. operationalized) by using relatively short understandable statements, as much as possible. For example, the goal concerning "the fight against corruption and crime" was expressed through the statement "creating general conditions for fighting corruption and crime", environmental objectives were expressed with the statement of "preventing the pollution of the environment and ensuring a healthy living environment", "material standard" (as a personal goal) with the statement of "providing me with as much money and other material goods", "social engagement" with the statement of "actively participating in social life, fighting for the achievement of important social goals." etc. Respondents were offered five answer modalities (to explore the degree of acceptance of specific objectives): "it matters little," "moderately important," "quite important", "very important" and "extremely important." Respondents were asked to circle the last answer only if they considered that certain objectives were extremely important. In addition, in order to determine the preference of objectives (priority value), the respondents were asked to single out five objectives that they considered most important, and 
then to isolate from these the one which is the most important for them, in their opinion (Kuzmanović and Petrović, 2007).

3) The model of instrumental rationality included the personal goals of pro-individual orientation: "reputation", "friends", "social power", "selfactualization", "exciting life", "safety", "material standards", "knowledge", "enjoyment", "independence", "popularity" and "healthy life".

4) The model of value rationality, on the other hand, included the objectives of pro-social orientation: "a strong economy", "good international relations", "the fight against corruption and crime", "strengthening defense forces", "humane relations", "environmental objectives", "employment", “social equality", "The rule of law", "preservation of tradition", "the privatization of public enterprises", "democracy", "living standards", "development of science and technology", "social rights", "altruism", "achievement", "subordination", "conscientiousness" and "social engagement".

\subsection{The Sample}

The study was conducted in May-June of 2014 on samples no. I and II. Sample no. I consisted of 268 first-year students of the Faculty of Economics in Nis. Model II consisted of 133 students of third and fourth grade of the School of Economics in Bujanovac. In the first sample, there was a total of 83 students (30.97\%) and 185 female students $(69.03 \%)$. The second sample consisted of 53 students (39.85\%) and 80 female students $(60.61 \%)$. The majority of respondents in the sample stated that one of their parents had four years of secondary education (45.6\%), followed by those who had a university degree $(39.7 \%)$, then an associate degree $(11.8 \%$ ), while only $2.9 \%$ completed only primary school. More than half of the respondents stated that their families lived well $(51.47 \%)$, slightly more than a quarter $(26.47 \%)$ stated that they lived moderately, $21.38 \%$ of them described the quality of life in their families as "bearable", and $0.68 \%$ of respondents said that they had a hard life. The majority of respondents in sample II answered that one of their parents had four years of secondary education $(54.4 \%)$, followed by those who had an associate degree $(24 \%)$ and university degree $(21.6 \%)$. In sample II, the highest percentage of respondents stated that their families lived well (42\%), 24\% of them said they lived moderately, $10 \%$ of them described the quality of life in their families as "bearable", $12 \%$ of respondents said that they had a hard life, and the same percentage stated that they lived intolerable.

\subsection{Analysis of The Results}

In determining the degree of acceptance of goals and structure of goals that individuals accept or not, the following descriptive measures were used: the average acceptance of each objective (as we respond to the scale of assessment scores in 1 to 5) with the following data on the scattering rate (SD), the frequency of occurrence of (each) of the five priority objectives (expressed by the percentage of respondents who chose the goal) and the percentage of respondents who opted for the goal as the most important.

In the sample of students of the Faculty of Economics in Nis, the highest average score (4.95) was achieved by the goal named "standard material" (Table 1). Seventyfive respondents put the goal $(27.9 \%)$ among the five prioritized ones and twenty-four of the 
respondents $(8.95 \%)$ elected this goal as the most important. "Friends" were in the second place, with an average score of 4.59 . This option was ranked among the top five priority objectives by sixty three of the respondents $(23.51 \%)$, but only sixteen respondents elected it as the most important goal in life (5.97\%). The third-ranked goal is the one of "social power" ("undertaking actions which, by their repetitive and systematic character, influence the lives of others") with an average score of 4.53. "Independence" was found on the fourth place with avarege score 4,50 and 118 of respondents (44.02\%) named this gaol as one of 5 most important, and sixteen of the respondents selected this goal as the most important goal in life (5.97\%). The fith ranked goal is "employment" (4.43), 169 (63.05\%) of respondents marked this goal as most important and it is the first ranked among the five prioritized. High ratings (above 4) were given to these objectives: "the standard of living" (4.42), "enjoyment" (4.39), "security" (4.38), "popularity" (4.33), "achievement" (4.25), "reputation" (4.25), "the development of science and technology" (4.19), "healthy life" (4.19), "self-actualization" (4.17), "exciting life" (4.01), "knowledge" (4.01), "the fight against corruption and crime" (4), and "a strong economy" (3.94). An intermediate level of acceptance (estimated between 3 and 4) was registered at the objectives: "conscientiousness" (3.92), "social engagement" (3.88), "altruism" (3.86), "love" (3.78), "social equality" (3.58), "human relations" (3.40), and "environmental targets" (3.36). The lowest ratings were given to: "democracy" (3.10), "the preservation of tradition" (2.39), "the state of law" (2.33), "the privatization of public enterprises" (2.02), "subordination" (1.77). None of these objectives were designated as the most important.

Table 1 Personal and social goals (The Faculty of Economics)

\begin{tabular}{|c|c|c|c|c|c|c|c|c|c|}
\hline \multirow{2}{*}{ Goals } & \multirow{2}{*}{ AS } & \multirow{2}{*}{$\mathrm{SD}$} & \multirow{2}{*}{$\begin{array}{l}\text { Ranking } \\
\text { by AS }\end{array}$} & \multicolumn{2}{|c|}{$\Sigma 1-5$} & \multirow[t]{2}{*}{$\begin{array}{l}\text { Ranking } \\
\text { by } 5 \\
\text { preferences }\end{array}$} & \multicolumn{2}{|c|}{$\begin{array}{l}\text { The most } \\
\text { important }\end{array}$} & \multirow{2}{*}{$\begin{array}{c}\text { Ranking as } \\
\text { the most } \\
\text { important }\end{array}$} \\
\hline & & & & $\mathrm{f}$ & $\%$ & & $\mathrm{f}$ & $\%$ & \\
\hline Strong economy & 3.94 & 0.97433 & 19 & 24 & 8.82 & $16-19$ & & & \\
\hline Good international relationships & 3.14 & 1.54482 & 27 & 0 & 0 & / & & & \\
\hline $\begin{array}{l}\text { Fight against crime and } \\
\text { corruption }\end{array}$ & 4 & 0.88941 & $17-18$ & 16 & 5.88 & 20 & 4 & 1.47 & $14-16$ \\
\hline $\begin{array}{l}\text { Strengthenimg the defence } \\
\text { forse }\end{array}$ & 3.13 & 1.18049 & 28 & 0 & 0 & / & & & \\
\hline More humane relations & 3.40 & 1.19252 & 25 & 8 & 2.94 & $24-25$ & & & \\
\hline Environmental goals & 3.36 & 1.28154 & 26 & 8 & 2.94 & $24-25$ & & & \\
\hline Employment & 4.43 & 0.92276 & 5 & 169 & 63.23 & 1 & 32 & 11.76 & 3 \\
\hline Social equality & 3.58 & 1.13081 & 24 & 24 & 8.82 & $16-19$ & 8 & 2.94 & $8-13$ \\
\hline The state of law & 2.33 & 1.53848 & 31 & 32 & 11.76 & 15 & & & \\
\hline Preservation of tradition & 2.39 & 1.23954 & 30 & 32 & 11.76 & 15 & & & \\
\hline $\begin{array}{l}\text { Privatization of public } \\
\text { enterprises }\end{array}$ & 2.02 & 1.40292 & 32 & 12 & 4.41 & $21-23$ & & & \\
\hline Democracy & 3.10 & 1.40935 & 29 & 0 & 0 & 1 & & & \\
\hline Standard of living & 4.42 & 0.7879 & 6 & 39 & 14.70 & $12-13$ & & & \\
\hline $\begin{array}{l}\text { The development of science } \\
\text { and tech. }\end{array}$ & 4.19 & 0.84725 & $12-13$ & 47 & 17.65 & 11 & 4 & 1.47 & $14-16$ \\
\hline Social rights & 4.00 & 0.76305 & $17-18$ & 63 & 23.53 & 8 & 16 & 5.88 & $6-7$ \\
\hline Reputation & 4.25 & 0.96391 & $10-11$ & 4 & 1.47 & $25-28$ & & & \\
\hline Friends & 4.59 & 0.53848 & 2 & 63 & 23.35 & 15 & & & \\
\hline
\end{tabular}




\begin{tabular}{|l|c|c|c|c|c|c|c|c|c|}
\hline Social power & 4.53 & 1.17754 & 3 & 54 & 20.25 & $/$ & & & \\
\hline Self-actualization & 4.17 & 0.84523 & 14 & 24 & 8.82 & $/$ & & & \\
\hline Altruism & 3.86 & 1.10503 & 22 & 35 & 13.23 & 14 & 8 & 2.94 & $8-13$ \\
\hline Achievement & 4.25 & 1.00517 & $10-11$ & 52 & 19.11 & $9-10$ & 8 & 2.94 & $8-13$ \\
\hline Exciting life & 4.01 & 1.16534 & $15-16$ & 78 & 29.41 & 5 & 16 & 5.88 & $6-7$ \\
\hline Subordination & 1.77 & 1.20755 & 33 & 4 & 1.47 & $25-28$ & & & \\
\hline Security & 4.38 & 0.87536 & 8 & 122 & 45.59 & 2 & 47 & 17.65 & 1 \\
\hline Conscientiousness & 3.92 & 2.27258 & 20 & 52 & 19.11 & $9-10$ & 8 & 2.94 & $8-13$ \\
\hline Love & 3.17 & 1.06904 & 23 & 12 & 4.41 & $21-23$ & & & \\
\hline Material standard & 4.95 & 1.56534 & 1 & 75 & 27.94 & 6 & 24 & 8.82 & $4-5$ \\
\hline Knowledge & 4.01 & 1.02132 & $15-16$ & 0 & 0 & $/$ & & & \\
\hline Enjoyment & 4.39 & 0.79666 & 7 & 91 & 33.82 & 4 & 43 & 16.17 & 2 \\
\hline Social engagement & 3.88 & 1.04424 & 21 & 4 & 1.47 & $25-28$ & & & \\
\hline Independence & 4.50 & 0.82421 & 4 & 118 & 44.12 & $16-19$ & 16 & 5.88 & $14-16$ \\
\hline Popularity & 4.33 & 0.83079 & 9 & 71 & 26.47 & 7 & & & \\
\hline Healthy life & 4.19 & 0.88296 & $12-13$ & 39 & 14.70 & $12-13$ & & & \\
\hline
\end{tabular}

Source: Authors'calculation (SPSS statistics)

The analysis of average grades in a sample of students of the Faculty of Economics indicates that young people gravitate towards primarily egoistic, selfish goals (material standard, enjoyment, security, independence, etc.), and not some sublime ideals (democracy, good international relations, state of altruism). Respondents were most focused on their own desires and needs, without too much respect for the wishes and needs of other people (Table 1). Each individual in the sample behaves according with its own interests, not having at this idea of the consequences of their decisions on society as a whole (Stefanović, 2012).

In the study by Kuzmanovic and Petrovic on the preferences of individual and social goals of high school students, the highest average grade (4.60) was received by the goal "friends", which cited: "Yes, I have friends who will support me, and that I can rely on in any situation" (Kuzmanovič and Petrović, 2007). The greatest number of respondents $(70 \%)$ ranked this goal in the top five by priority, and the most of respondents also elected the goal as the most important personal goal (23.5\%). "Employment" came in second place with an average score of 4.49 . This goal was identified as the most important by $15 \%$ of the respondents, and the same percentage of respondents ranked it among the top five by priority. The third-ranked was the goal "love" (finding a suitable partner) 4.46. The two thirds of respondents $(66 \%)$ incorporated "love" in the top five priority objectives but only a tenth of the respondents elected it as the most important goal in life. It may sound a bit paradoxical, but practically the same average score was given to the goal of "being completely independent and not dependent on anyone", which was chosen as the most important goal by a larger number of participants than "love" (15\%) (Kuzmanovič and Petrović, 2007). High scores (above 4) were given to these objectives too: "the material standard" (4.27), "self-actualization", or "the expression of their own abilities and capabilities" (4.24), "the acquisition of knowledge" (4.19) (Kuzmanovič and Petrović, 2007). The least important goals for the respondents are: the acceptance of subordination (2.35) and social engagement (2.98). This sample of youngs, on the one hand, tends to independence, self-actualization and competence, and on the other 
hand, the material and living standards. Research on Structure of preference personal and social goals of high school by Kuzmanovic and Petrovic, produced empirical results that show that individuals exhibit behaviour consistent with the model of of instrumental rationality.

When it comes to personal and social goals of respondents in the sample of pupils of the Vocational School of Economics (Table 2), the highest average value was received by "knowledge" ("gaining higher education and achieving higher living standards"), immediately followed by "environmental objectives". Sixty-eight of the respondents (.51\%)arked "employment" as one of 5 most significant. "Environmental objectives" were marked as one of five prioritized by 89 of the respondents (66.9\%). According to the average score of the respondents, very important objectives are: "achievement" (4.18), "the fight against corruption and crime" (4.1), "love" (4.1), "material standard", (4), "healthy life" (4), "employment" (4) and "social rights" (3.97). The least accepted (from offered) goals are: "privatization of public enterprises" (2.22), "state of law" (2.61), "friends" (2.27), "social power" (2.94), "popularity" (3.12), "enjoyment" (3.31), "altruism" (3.31), "a strong economy" (3.39), and "subordination" (3.41). No one included the privatization of public enterprises among the top five priority objectives. Likewise, no one selected it as the most important goal.

Table 2 Personal and social goals (Vocational School of Economics in Bujanovac)

\begin{tabular}{|c|c|c|c|c|c|c|c|c|c|}
\hline \multirow[t]{2}{*}{ Goals } & \multirow[t]{2}{*}{ AS } & \multirow[t]{2}{*}{ SD } & \multirow[t]{2}{*}{$\begin{array}{c}\text { Rank by } \\
\text { AS }\end{array}$} & \multicolumn{2}{|c|}{$\Sigma 1-5$} & \multirow[t]{2}{*}{$\begin{array}{c}\text { Ranking } \\
\text { by } 5 \\
\text { preferences }\end{array}$} & \multicolumn{2}{|c|}{$\begin{array}{l}\text { The most } \\
\text { important }\end{array}$} & \multirow{2}{*}{$\begin{array}{c}\text { Ranking as } \\
\text { the most } \\
\text { important }\end{array}$} \\
\hline & & & & $\mathrm{f}$ & $\%$ & & $\mathrm{f}$ & $\%$ & \\
\hline Strong economy & 3.39 & 1.1973 & 26 & 1 & .75 & $22-26$ & 4 & 3.03 & $10-15$ \\
\hline $\begin{array}{l}\text { Good international } \\
\text { relationships }\end{array}$ & 3.42 & 1.1233 & $22-24$ & 2 & 2 & $17-21$ & 8 & 6.06 & $6-9$ \\
\hline $\begin{array}{l}\text { Fight against crime and } \\
\text { corruption }\end{array}$ & 4.1 & 0.9541 & $4-5$ & 16 & 12.12 & $10-12$ & 4 & 3.03 & $10-15$ \\
\hline $\begin{array}{l}\text { Strengthening the defense } \\
\text { forces }\end{array}$ & 3.42 & 1.2507 & $22-24$ & 0 & 0 & / & & & \\
\hline More humane Relation. & 3.91 & 0.97995 & 10 & 12 & 9.09 & $14-16$ & & & \\
\hline Environmental objectives & 4.45 & 0.86931 & 2 & 89 & 66.9 & 6 & & & \\
\hline Employment & 4 & 1.0606 & $6-8$ & 68 & 51.12 & $10-12$ & 68 & 51,12 & $10-15$ \\
\hline Social equality & 3.75 & 1.19324 & 16 & 0 & 0 & 1 & & & \\
\hline The state of law & 2.61 & 1.06649 & 32 & 8 & 6.06 & $18-20$ & & & \\
\hline Keeping the tradition & 3.78 & 1.36509 & 15 & 8 & 6.06 & 19 & & & \\
\hline $\begin{array}{l}\text { Privatization of public } \\
\text { enterprises }\end{array}$ & 2.22 & 1.14813 & 33 & 0 & 0 & / & & & \\
\hline Democracy & 3.45 & 1.10869 & 21 & 4 & 3.03 & $22-26$ & & & \\
\hline Living Standard & 3.67 & 1.43680 & $17-18$ & 8 & 6.02 & $18-20$ & & & \\
\hline $\begin{array}{l}\text { The development of science } \\
\text { and technol. }\end{array}$ & 3.42 & 1.04541 & $22-23$ & 16 & 12.12 & $10-12$ & & & \\
\hline Social rights & 3.97 & 1.16616 & 9 & 24 & 18.18 & 8 & 4 & 3.03 & $10-15$ \\
\hline Prestige & 3.88 & 1.44206 & 11 & 48 & 36.36 & 13 & & & $2-5$ \\
\hline Friends & 2.27 & 1.32147 & 31 & 4 & 3.03 & $22-26$ & & & \\
\hline Social power & 2.94 & 1.3444 & 30 & 0 & 0 & 1 & & & \\
\hline Self-actualization & 3.48 & 1.33428 & 19 & 0 & 0 & 1 & & & \\
\hline
\end{tabular}




\begin{tabular}{|l|c|c|c|c|c|c|c|c|c|}
\hline Altruism & 3.31 & 1.28585 & $27-28$ & 28 & 21.21 & 7 & 28 & 21.21 & $6-9$ \\
\hline Achievement & 4.18 & 1.17586 & 3 & 21 & 15.15 & 9 & 12 & 9.09 & $6-9$ \\
\hline Exciting life & 3.84 & 1.23742 & $12-14$ & 4 & 3.03 & $22-26$ & & & \\
\hline Subordination & 3.41 & 1.12882 & 25 & 0 & 0 & $/$ & & & \\
\hline Security & 3.67 & 1.32108 & $17-18$ & 0 & 0 & $/$ & & & \\
\hline Conscientiousness & 3.47 & 1.4 & 25 & 44 & 33.33 & 4 & & & \\
\hline Love & 4.1 & 1.4 & $4-5$ & 53 & 39.39 & 2 & 16 & 12.12 & 1 \\
\hline Material standard & 4 & 1.2119 & $6-8$ & 36 & 27.27 & 5 & 8 & 6.06 & $6-9$ \\
\hline Knowledge & 4.48 & 0.83372 & 1 & 68 & 51.51 & 1 & 12 & 9.09 & $2-5$ \\
\hline Pleasure & 3.31 & 1.51007 & $27-28$ & 12 & 9.09 & $14-16$ & & & \\
\hline Social engagement & 3.84 & 1.09322 & $12-14$ & 4 & 3.03 & $22-26$ & & & \\
\hline Independence & 3.84 & 1.18486 & $12-14$ & 0 & 0 & $/$ & 12 & 9.09 & $2-5$ \\
\hline Popularity & 3.12 & 1.38648 & 29 & 0 & 0 & $/$ & 4 & 3.03 & $10-15$ \\
\hline Healthy life & 4 & 1.42521 & $6-8$ & 12 & 9.09 & $14-16$ & & & \\
\hline
\end{tabular}

Source: Authors'calculation (SPSS statistics)

The analysis of the average marks in sample II reveals the desire of participants to make their peers feel pleasant and satisfied because of their favorable attitude, and pain because of their unfavorable attitude (Smit, 2008). Order and progress of society are something that suits the respondents in sample II and something they think about with pleasure.

Unlike the results of the analysis of the sample of students in the Faculty of Economics, which showed that homoeconomisus, in order to satisfy their own desires and needs, dispels its rivals, such as homoethicus, homoempathicus, the side of a man which tend to cooperation and reciprocity (Cohen, 2014), the results of the sample of pupils of the Vocational School of Economics reveal another side of a man, and that is homosipaticus. While homoeconomisus, continuously calculates in order to increase their own prosperity, to some extent, homosipaticus takes into account the interests of other people and the society in which he lives (Dekić, 2013).

In the case of the sample of pupils of the Vocational School of Economics, research has shown that economists can not adequately explain the behaviour of people if they are focused only on the observation from the model of instrumental rationality. The research results clearly show that trust, cooperation and reciprocity are important factors of rational behaviour (from the viewpoint of the model value rationality).

\subsection{Factor Structure of Personal and Social Goals}

From the personal goals of the students of the Faculty of Economics, the six factors that explain $75 \%$ of the variance of results (Table 3 ) were extracted. Five components that explain $71 \%$ of the variances (Table 4 ) were extracted from the social objectives of the same sample. Based on the sample of students of the School of Economics in Bujanovac, two lists of the six factors for exploring the structure of preferences of individual and social goals (Table 5 and Table 6) were created. These factors account for $68 \%$ of result variances for personal and $65 \%$ of the result variances for social goals. We presented the matrix structure of personal and social goals for both samples. (In the factor analysis, special attention was paid to loads greater than 0.40 ). 
When it comes to the analysis of different targets in sample no. I, "reputation", "exciting life", "safety", "love", "material standards", "knowledge", "independence" and "healthy life" (indicators of instrumental rationality) are dominant in the first factor (Table 3). The second factor involves individualized behaviour including the popularity and orientation towards "enjoyment", "social power", "friends" and an "exciting life" to a great extent. At the third factor, indicators of individualized behaviour have the largest factor loading ("social power", "self-actualization" and "healthy life"). The fourth factor emphasizes moral values in the foreground ("altruism"). The fifth factor indicates the restraint from inappropriate behaviour, acting according to the principle of prudence, justice, and true compassion ("conscientiousness"), as well as active participation in social life ("the social engagement"). The sixth factor potentiates the desire of the individual to be praised and admired ("enjoyment").

Table 3 Factor structure of personal goals (The Faculty of Economics in Nis)

\begin{tabular}{|l|c|c|c|c|c|c|}
\hline \multicolumn{1}{|c|}{ Personal goals } & $\mathbf{1}$ & $\mathbf{2}$ & $\mathbf{3}$ & $\mathbf{4}$ & $\mathbf{5}$ & $\mathbf{6}$ \\
\hline Reputation & $\mathbf{. 5 7 9}$ & -.028 & $-\mathbf{4 4 4}$ & -.305 & .286 & -.124 \\
\hline Friends & -.068 & $\mathbf{. 5 9 9}$ &, 382 &.$- \mathbf{4 0 6}$ & .330 & -.032 \\
\hline Social power & -.047 & $\mathbf{. 6 5 1}$ & $\mathbf{, 5 9 4}$ & -.137 & -.091 & .139 \\
\hline Self-actualization & .304 & .342 & $\mathbf{5 5 0}$ & -.091 & -.310 & -.135 \\
\hline Altruism & .193 & -.047 &,- 284 & $\mathbf{. 6 6 3}$ & .297 & .219 \\
\hline Achievement & $\mathbf{. 4 5 8}$ & -.265 &,- 133 & -.377 & .334 & .274 \\
\hline Exciting life & $\mathbf{. 6 1 1}$ & $\mathbf{. 5 3 5}$ &, 133 & .198 & -.233 & -.15 \\
\hline Subordination & -.002 & -.296 & $\mathbf{4 6 3}$ & .220 & $\mathbf{. 5 5 6}$ & -.301 \\
\hline Safety & $\mathbf{. 6 0 1}$ & -.339 &, 011 & -.268 & -.289 & -.00 \\
\hline Conscientiousness & $\mathbf{. 4 9 8}$ & $\mathbf{- . 4 4 9}$ & $\mathbf{, 4 0 7}$ & -.177 & $\mathbf{. 4 0 3}$ & .215 \\
\hline Love & $\mathbf{. 5 9 1}$ & -.392 &, 297 & .393 & -.109 & .091 \\
\hline Material standard & $\mathbf{. 6 7 5}$ & .035 &,- 246 &.- .557 & -.072 & -.022 \\
\hline Knowledge & $\mathbf{. 5 9 0}$ & .052 &,- 307 & .388 & -.320 & -.166 \\
\hline Enjoyment & .333 & $\mathbf{. 6 0 8}$ &,- 184 & .126 & -.017 & $\mathbf{. 5 1 8}$ \\
\hline Social engagement & .105 & $\mathbf{. 5 4 1}$ &,- 116 & .373 & $\mathbf{. 4 3 8}$ & -.340 \\
\hline Independence & $\mathbf{. 4 4 6}$ & .266 &,- 119 & -.012 & .163 & -.527 \\
\hline Popularity & .162 & $\mathbf{. 5 5 2}$ &,- 240 & .019 & .280 & .359 \\
\hline Healthy life & $\mathbf{. 6 8 3}$ & -.201 & $\mathbf{5 1 7}$ & .286 & -.060 & .276 \\
\hline
\end{tabular}

Source: Authors' calculation (SPSS statistics)

The analysis of the first, the second, the third and the sixth factors shows that respondents in sample no. I exhibit behaviour that is consistent with the model of instrumental rationality, where the individual egotistical interests are crucial (Table 3). As the supporters of the instrumental rationality believe, people have the right to use all the means for accomplishing individual interests in the best way. The analysis of the fourth and fifth factors primarily emphasizes moral behaviour. According to the representatives of instrumental rationality, moral behaviour is the product of egoism (Becker, 1976). For example, when we help others, we actually demonstrate our power and, thus, we pamper ourselves. When we pity or sympathize with others, we actually pity ourselves imagining a future accident that could happen to us. Basically, people never honestly work for the welfare of others. The actions of people are always derived from personal interest, ambition and lust (Sadžakov, 2011). 
Judging by the first factor, the young respondents in sample I strive towards modernization, progress of the state, and also stress the desire for preserving national identity, traditions and customs as an important issue (Table 4). Factor two emphases:"strong economy", "the privatization of public enterprises", "more humane relations", "environmental goals". Factor three combines "environmental goals", "tradition" and "standard of living". The participants of this study apparently believe that the increase of the living standard and preservation of tradition will ensure a higher level of social welfare. In addition, the analysis of the third factor clearly and unambiguously shows that respondents are aware of the fact that instrumental rationality can show itself to be harmful from the point of view of society and its valuable objectives. That is why respondents prefer value and expressive rationality and control egotistical interests. ${ }^{1}$ Factors four and five point out "privatization of public firms" as a goal of the highest importance.

Table 4. Factor structure of social goals (Faculty of Economics in Nis)

\begin{tabular}{|l|c|c|c|c|c|}
\hline \multicolumn{1}{|c|}{ Social goals } & $\mathbf{1}$ & $\mathbf{2}$ & $\mathbf{3}$ & $\mathbf{4}$ & $\mathbf{5}$ \\
\hline Strong economy & $\mathbf{. 5 0 2}$ & $\mathbf{. 6 5 3}$ & -.290 & -.131 & .092 \\
\hline Good (Humane) intentional relationships & $\mathbf{. 5 6 3}$ & .368 & -.127 & .262 & -.424 \\
\hline Fight against crime and corruption & $\mathbf{. 6 5 9}$ & -.176 & .137 & -.219 & -.395 \\
\hline Strengthening the defense forces & $\mathbf{. 6 4 3}$ & -.027 & .244 & .088 & .286 \\
\hline More humane relations & $\mathbf{. 5 5 0}$ & $\mathbf{- . 4 3 4}$ & $\mathbf{- . 4 8 5}$ & .209 & .073 \\
\hline Environmental goals & .342 & $\mathbf{- . 6 9 5}$ & $\mathbf{. 4 0 9}$ & .216 & .196 \\
\hline Employment & $\mathbf{. 4 3 5}$ & .015 & -.165 & $\mathbf{- . 5 8 7}$ & .392 \\
\hline Social equality & $\mathbf{. 7 0 4}$ & .053 & .109 & .139 & .1333 \\
\hline The state of law & $\mathbf{. 6 1 7}$ & .155 & -.406 & -.133 & .026 \\
\hline Tradition & $\mathbf{. 4 5 1}$ & .141 & $\mathbf{. 4 6 2}$ &.$- \mathbf{4 7 5}$ & .136 \\
\hline Privatization of public enterprises & .011 & $\mathbf{. 4 8 2}$ & .289 & $\mathbf{. 5 1 0}$ & $\mathbf{. 5 0 7}$ \\
\hline Democracy & $\mathbf{. 7 2 4}$ & .030 & .026 & .372 & -.253 \\
\hline Standard of living & $\mathbf{. 6 0 7}$ & .095 &. $\mathbf{6 1 1}$ & -.177 & -.296 \\
\hline The development of science and technologhy & $\mathbf{. 7 2 0}$ & .075 & -.022 & .210 & .121 \\
\hline Social rights & $\mathbf{. 6 8 3}$ & -.389 & -.355 & -.071 & .131 \\
\hline
\end{tabular}

Source: Authors'calculation (SPSS statistics)

As suggested by the first factor, generosity, social security (parents, relatives and friends), acting according to the principle of justice and genuine compassion are essential virtues and are very useful for people (Table 5). A high correlation of "altruism", "achievement", "subordination", "conscientiousness" and "love" with factor 1 means that a part of the respondents believe that man is also governed by some motives that are different from personal interest. Philanthropy, justice, generosity and the need for social happiness are essential virtues and, as such, they are very useful for people (Smith, 1985). The second factor figures only personal objectives of pro-individual orientation. The fourth factor emphasizes the opportunistic behaviour or the exploitation of opportunities for the realization of one's own needs. In accordance with the fifth factor, for the respondents of sample I, enjoying their own and others' achievements is important. The focus of the last factor is solely egoism, or the care for personal interest. Moreover, the factor analysis of preference personal goals in sample II confirms the hypothesis of the 
experiment that the model of instrumental rationality explains human behaviour better than the model of value rationality.

Table 5 Factor Structure of Personal Goals (of the School of Economics in Bujanovac)

\begin{tabular}{|l|c|c|c|c|c|c|}
\hline \multicolumn{1}{|c|}{ Personal goals } & $\mathbf{1}$ & $\mathbf{2}$ & $\mathbf{3}$ & $\mathbf{4}$ & $\mathbf{5}$ & $\mathbf{6}$ \\
\hline Prestige & -.151 & $\mathbf{. 5 9 0}$ & -.285 & .289 & -.237 & .028 \\
\hline Friends & $\mathbf{- . 5 3 6}$ & .277 & .013 &.$- \mathbf{4 1 4}$ & -.307 & .145 \\
\hline Social power & -.309 & .353 & -.257 & $\mathbf{. 4 0 7}$ & $\mathbf{- . 6 2 2}$ & -.058 \\
\hline Self-actualization & $\mathbf{. 4 7 8}$ & $\mathbf{. 5 0 0}$ & .212 & .040 & -.263 & .261 \\
\hline Altruism & $\mathbf{. 6 6 1}$ & .017 & -.220 & .230 & .135 & .113 \\
\hline Achievement & $\mathbf{. 7 8 0}$ & .215 & .003 & -.072 & -.008 & .162 \\
\hline Exciting life & .235 & $\mathbf{. 4 7 3}$ & $\mathbf{- . 4 0 6}$ & -.179 & -.011 & -.081 \\
\hline Subordination & $\mathbf{. 5 9 7}$ & .332 & .262 & -.120 & -.056 & -.325 \\
\hline Security & -.054 & $\mathbf{. 5 9 6}$ & $\mathbf{. 4 4 8}$ & -.381 & .022 & -.028 \\
\hline Conscientiousness & $\mathbf{. 6 9 9}$ & .160 & -.168 & .192 & .174 & -.278 \\
\hline Love & $\mathbf{. 7 6 4}$ & .158 & .141 & .078 & -.071 & -.066 \\
\hline Material standard & $\mathbf{. . 5 3 0}$ & $\mathbf{. 5 2 9}$ & .178 & -.200 & .212 & -.075 \\
\hline Knowledge & -.217 & .229 & $\mathbf{. 6 7 0}$ & .374 & .171 & .206 \\
\hline Enjoyment & -.215 & $\mathbf{. 6 8 4}$ & -.128 & -.003 & $\mathbf{. 4 3 2}$ & -.186 \\
\hline Social engagement & -.292 & .182 & -.293 & .399 & .371 & $\mathbf{. 4 8 7}$ \\
\hline Independence & -.129 & $\mathbf{. 4 1 3}$ & $\mathbf{. 5 0 6}$ & $\mathbf{. 4 6 9}$ & -.039 & -.140 \\
\hline Popularity & -.275 & $\mathbf{. 5 4 0}$ & $\mathbf{- . 5 0 0}$ & -.022 & .132 & -.243 \\
\hline Healthy life & .382 & $\mathbf{. 4 1 4}$ & -.121 & -.321 & .004 & $\mathbf{. 5 6 7}$ \\
\hline
\end{tabular}

Source: Authors' calculation (SPSS statistics)

The first factor includes: "a strong economy", "the fight against corruption and crime", "more human relations", "social equality", "preserving tradition" and "democracy" (Table 6). From the analysis of the second factor, it follows that the creation of general conditions for fighting corruption and crime (under the second factor, the fight against corruption and crime has the highest arithmetic value) will contribute to the preservation of moral values. The second factor summarizes fight against corruption and crime (.477), strengthening defense forces (.462) and preservation of tradition (.492). The realization of these goals is in the function of the preservation of territorial integrity and achieving better standard. As the third factor suggests, for the future, it is important to increase employment and develop good international relationships, which should accelerate the process of Serbia's accession to the EU. The privatization of public enterprises and the standard of living prevail within the fourth factor. The achievement of these goals is in the function of strengthening the market economy and material standard (material standard as a personal goal and standard of living as a social goal have contextually similar) As no one included the privatization of public enterprises as one of the top five priority objectives in sample II, and as no one marked it as the most important goal, we concluded that an efficient management of public enterprises would create the conditions necessary for the growth of living standards. Careful examination of the fifth factor shows the role of science and technology in increasing the efficiency and results in transactions and communications of economic actors. The sixth factor 
clearly points out the importance of preserving and improving the environment for the development of society.

Table 6 Factor structure of social goals (of the School of Economics in Bujanovac)

\begin{tabular}{|l|c|c|c|c|c|c|}
\hline \multicolumn{1}{|c|}{ Social goals } & $\mathbf{1}$ & $\mathbf{2}$ & $\mathbf{3}$ & $\mathbf{4}$ & $\mathbf{5}$ & $\mathbf{6}$ \\
\hline Strong economy & $\mathbf{. 4 7 7}$ & -.103 & -.023 & .069 & $\mathbf{. 6 0 9}$ & -.283 \\
\hline Good international relationships & .288 & -.448 & $\mathbf{. 4 7 0}$ & .112 & -.101 & .204 \\
\hline Fight against corruption and crime & $\mathbf{. 4 5 3}$ & $\mathbf{. 4 7 7}$ & -.088 & -.036 & -.497 & -.220 \\
\hline Strengthening defense forces & .167 & $\mathbf{. 4 6 2}$ & .295 & .301 & .063 & .259 \\
\hline More humane relations & $\mathbf{. 5 0 6}$ & -.372 & .106 & -.426 & -.184 & .011 \\
\hline Environmental goals & .264 & -.020 & .189 & -.380 & .212 & $\mathbf{. 6 7 0}$ \\
\hline Employment & .377 & -.253 & $\mathbf{. 4 8 5}$ & -.163 & -.359 & -.310 \\
\hline Social equality & $\mathbf{. 6 5 3}$ & .159 & .035 & .0095 & -.110 & -.036 \\
\hline The state of law & .360 & -.346 & -.528 & .166 & -.026 & -.173 \\
\hline Preservation of tradition & $\mathbf{. 5 7 2}$ &. $\mathbf{4 9 2}$ & -.238 & -.071 & -.108 & .195 \\
\hline Privatization of public enterprises & .039 & -.005 & .572 & $\mathbf{. 5 8 7}$ & .091 & -.178 \\
\hline Democracy & $\mathbf{. 6 2 6}$ & -.437 & .000 & .217 & .129 & .084 \\
\hline Living standard & .388 & -.217 & -.401 & $\mathbf{. 5 0 0}$ & -.034 & .249 \\
\hline Development of science and technology & .382 & .279 & .090 & -.371 & $\mathbf{. 5 0 8}$ & -.316 \\
\hline Social rights & .211 &. $\mathbf{7 7 7}$ & .129 & .147 & .051 & -.002 \\
\hline
\end{tabular}

Source: Authors'calculation (SPSS statistics)

When it comes to the factor analysis of personal preferences and social goals of high school students, Kuzmanović and Petrović have isolated up to seven factors from both lists of goals (Table 7 and Table 8 ). In the factor analysis, they paid special attention to loads greater than 0.30 .

The first factor was named "selfless fulfillment of duty", because it involves "altruism", "subordination" or "the enforcement of decisions", "conscientious life", and "social engagement" (Table 7). The third factor is related to competence and independence. The fourth factor gathers "friendly support", "love", "altruism" and "security". The sixth factor is hedonistic orientation. The factor analysis in Kuzmanović and Petrovićs research supports the hypothesis that rational actors exist in the sample (Kuzmanović and Petrović, 2007). The respondents in the sample are obvious examples of discrete purposeful actors who are able to consider a number of courses of action and to judiciously choose and implement one or more of them exist in the sample (Krstić, 2015). The largest number of goals arises from egoistical nature of human beings. Results of Kuzmanovic and Petrovic's factor analyzes also show that individuals in the sample are proned towards the market way of thinking and rational judgment.

Table 7 Factor structure of personal goals

\begin{tabular}{|l|c|c|c|c|c|c|c|}
\hline \multicolumn{1}{|c|}{ Personal goals } & $\mathbf{1}$ & $\mathbf{2}$ & $\mathbf{3}$ & $\mathbf{4}$ & $\mathbf{5}$ & $\mathbf{6}$ & $\mathbf{7}$ \\
\hline Prestige & & .55 & -.44 & & -.31 & & \\
\hline Friends & & & & -.80 & & & \\
\hline Social power & & .74 & & & & & \\
\hline Self-actualization & & & -.61 & & & .32 & .32 \\
\hline
\end{tabular}




\begin{tabular}{|c|c|c|c|c|c|c|c|}
\hline Altruism & .72 & & & -.41 & & & \\
\hline Achievement & & .51 & -.37 & & -.52 & & \\
\hline Exciting life & & & & & & .80 & \\
\hline Subordination & .76 & & & & & & \\
\hline Security & .41 & & & -.38 & & & .63 \\
\hline Conscientiousness & .56 & & & & & & .60 \\
\hline Love & & & & -.66 & & & \\
\hline Material standard & & & & & -.78 & & \\
\hline Knowledge & & & -.81 & & & & \\
\hline Hedonism & & & & & & .81 & \\
\hline Social engagement & 55 & & -.40 & & & & \\
\hline Independence & & & -.72 & & & & \\
\hline Popularity & & .71 & & & & & \\
\hline Healthy life & & & & & & & .83 \\
\hline
\end{tabular}

Source: Kuzmanović, B., Petrović, N. (2007), "Preferences Structure of Personal and Social Goals of the High-Schoolers”, Psyhology, Vol. 40, No. 4, p. 577.

The factor analysis of social goals (Table 8) from the research of Kuzmanović and Petrović indicates the division between traditionalism (showed by factor 2), on the one hand, and modernity, market economy and social security (reflected by factor 4), on the other hand. "Preservation of tradition", "territorial integrity" and "state integrity", are dominant in factor two, followed by strengthening "defense forces", to a significantly lesser extent."Entering the EU" and "good inter-ethnic relations" are at the other end. Factor 4 includes "social rights", "development of science" and "culture", "a strong market economy" and "employment" (Kuzmanović and Petrović, 2007).

Factor 4 corresponds to the social-democratic (ideological) framework, which implies accepting of market economy norms, strong and efficient state that will focus on strengthening and development of rules within which the individuals will be able to work on the acievement of their own, strictly private and personal goals. Factor 4 strongly correlates with the market economy (0.52) in which basis is the idea that only those who are rational (market capable, competing) should survive. Factor 2 corresponds to etatistic (state communist) ideological framework which is characterized by the state involvement in all spheres of economic and social life.

Table 8 Factor structure of social goals

\begin{tabular}{|l|c|c|c|c|c|c|c|}
\hline \multicolumn{1}{|c|}{ Social goals } & $\mathbf{1}$ & $\mathbf{2}$ & $\mathbf{3}$ & $\mathbf{4}$ & $\mathbf{5}$ & $\mathbf{6}$ & $\mathbf{7}$ \\
\hline Strong economy & & & .42 & -.52 & & & -.32 \\
\hline Good international relationships & .31 & -.37 & .36 & & .44 & .36 & \\
\hline Fight against corruption and crime & .79 & & & & & & \\
\hline Strengthening defense forces & & .38 & & & & -.58 & \\
\hline More humane relations & .59 & & & & .39 & .37 & \\
\hline Environmental goals & .61 & & & & & & .42 \\
\hline Employment & & & & -.32 & .75 & -.37 & \\
\hline Social equality & & & & & .77 & .33 & \\
\hline The state of law & .63 & & .31 & & & & \\
\hline Preservation of tradition & & .82 & & & & & \\
\hline
\end{tabular}




\begin{tabular}{|l|l|c|c|c|c|c|c|}
\hline Entering the EU & & -.39 & .67 & & & & \\
\hline Privatization & & & .82 & & & & \\
\hline Territorial and state integrity & & .817 & & & & & \\
\hline Democracy & .32 & & .35 & & & .67 & \\
\hline Living standard & & & & -.77 & & & \\
\hline Development of science and culture & .46 & & & -.64 & & & \\
\hline Social rights & & .71 & & -.64 & & & .44 \\
\hline The one-party system & & & & & & & .75 \\
\hline
\end{tabular}

Source: Kuzmanović, B., Petrović, N. (2007), "Preferences Structure of Personal and Social Goals of the High-Schoolers”, Psyhology, Vol. 40, No. 4, p. 577.

\subsection{One-factor Analysis of Variance}

In order to test the second hypothesis of the research, we applied the one-factor analysis of variance with planned comparisons. In the one-factor analysis of variance with planned comparisons, we examined whether a particular group is significantly different from another one in terms of instrumental and value rationality. (Pallant, 2009). In the one factor analysis of variance, there is only one independent variable (factor), divided into several levels or groups, or conditions (Pallant, 2009). In our research, the independent variable is the socioeconomic status of the family that is divided into five categories: "good", "fair", "tolerable", "difficult" and "unbearable".

Subjects were divided into three groups. The first group consists of subjects who assessed the socioeconomic of families as "good" and "mediocre". The second group consists of subjects who assessed the state of their families as "tolerable" and "difficult". The third group consists of the most vulnerable subjects (who assessed the socioeconomic situation of their families as "unbearable").

In the analysis of personal and social goals preferences of high school students and university students, the dependent variables are the objectives of pro-individual and pro-social orientation. In the sample Faculty of Economics in Nis, we chose the objective "material standard" as a dependent variable that was expressed through the statement "providing me with as much money and other material goods", while in the sample of pupils of the Vocational School of Economics, we chose the objective "subordination".2

The research of structure of personal and social goals preferences of students of Faculty of Economics in Nis, one-factor analysis of variance reveals is there a significant difference between the average value of the dependent variable "material standard" in group 1 and the average value of the dependent variable "material standard" in groups 2 and 3.

The main results of the one-factor analysis of variance with planned comparisons are shown in table 9. Since Levene's test (Pallant, 2009) showed that the difference of variance between groups was statistically insignificant (greater than 0.05), we applied the first row of the table "Assume Equal Variances" (Table 9). The significance of a given comparison, shown in column Sig. is 0.0042 . It is less than 0.05 , so we concluded that there was statistically significant difference in terms of respondents' instrumental rationality between group 1 and other groups. In other words, a statistically significant difference was identified, at $\mathrm{p}<0.05$ LOT results of groups: $\mathrm{F}(2,482)=4.15, \mathrm{p}=0.01$. Furthermore, the results of the research of personal and social goals preference of the Faculty of Economics' students confirm the second hypothesis of the experiment. 
Table 9 Contrast Tests

\begin{tabular}{|c|c|c|c|c|c|c|c|}
\hline \multirow{3}{*}{ ms. } & \multirow{3}{*}{$\begin{array}{l}\text { Assume equal variances } \\
\text { Does not assume equal variances }\end{array}$} & Contrast & $\begin{array}{l}\text { Value of } \\
\text { Contrast }\end{array}$ & Std. Error & $\mathrm{t}$ & $\mathrm{df}$ & Sig \\
\hline & & 1 & .21 & .333 & .632 & 67 & ,0042 \\
\hline & & 1 & .21 & .295 & .714 & 24,009 & .842 \\
\hline
\end{tabular}

Source: Authors'calculation (SPSS statistics)

In the sample of pupils of the Vocational School of Economics we chose as a dependent variable the objective "subordination" ("Do not acting out her inner feelings which everywhere and always provoke disgust and embarrassment"). All subjects in the sample II were divided into three groups. Starting from these settings, we asked: "Do the subjects from group 3 exhibit a higher degree of rationality value in relation to other subjects or not?".

The first column of Table 10 shows that the significance comparison of a given group is 0.0031 which is less than 0.05 . In line with this, there is a statistically significant difference between groups $(\mathrm{F}(2,432)=4.6)$. Furthermore, this means that the results of the analysis of the structure of students 'preferences confirm second research hypothesis.

Table 10 Contrast Test

\begin{tabular}{|ll|c|c|c|c|c|c|}
\hline & Contrast & $\begin{array}{c}\text { Value of } \\
\text { Contrast }\end{array}$ & Std. Error & $\mathrm{t}$ & Df & Sig \\
\hline Subord. & $\begin{array}{l}\text { Assume equal variances } \\
\text { Does not assume equal variances }\end{array}$ & 1 & -.42 & 1.452 & -.286 & 30 & .0031 \\
\cline { 2 - 9 } & 1 & -.42 & 2.100 & -.196 & 3.634 & .854 \\
\hline
\end{tabular}

Source: Authors'calculation (SPSS statistics)

\section{Limitations and Further Research}

The list of personal and social goals included relevant goals, but may lead to questions, such as whether we can formulate some other goals, whether some of the goals should be designed and called different etc. For instance, the goal "social rights" includes requirements for free education, health and social protection for all citizens, and these elements can be separated, on principle. However, citizens often perceived these elements as the sum of all social rights (Kuzmanović and Petrović, 2007). Is it better to talk about social justice instead of social rights? However, it is an even more general concept because, for many citizens, social justice includes the right to work, a fair wage, civil equality, solidarity, and material egalitarianism. Systematic research on this topic will show which and how many goals are the most economical and most adequately cover the entire field of personal and social goals. Factor analysis will indicate the possibility of a meaningful further generalization, while the analysis of the responses of different parts of the population, the reactions of the respondents and experts in this area will be the guideline for a possible reformulation of particular goals and for adding new goals to the list. 


\section{Conclusion}

The study had several objectives. The main objective of this study was to determine whether the model of instrumental rationality or value rationality explains the behaviour of participants of the research better. In this research, we examine the structure of acceptance of 18 personal and 15 social goals of high school students and university students. The results of analysis show that students tend towards primarily egoistic goals ("material standard", "friends", "social power", "independence", "enjoyment", "popularity" etc.). When it comes to personal and social goals of respondents in the sample of pupils of the Vocational School of Economics, the results (of analysis) reveal the pupils ' willingness to give up their personal utility for the common interest. Finally, the results of one-factor analysis confirm the second hypothesis of research according to which subjects whose assessed the socioeconomic situation of their families as "good" and "average", have higher levels of instrumental rationality.

Future researches should show how much are the goals stable and similar in various parts of the population, and whether we should include some new goals and elements. But, on the other hand, we should study more certain goals (their factors and impact on attitudes and behaviour) because they are relatively autonomous. Research on the preferences of personal and social goals of high school students and university students has certain disadvantages. First, the results of research can be unreliable due to disadvantages of data sources and methodological limitations, and "bounded rationality" of human cognition. There is no perfect methodology, and for this reason it is of great importance to combine methods and data sources (triangulation) in the social sciences. It should be pointed that there is no fully rational man, and that people are never valueneutral.

\section{References}

Becker, G. (1976). The Economic Approach to Human Behaviour. Chicago, University of Chicago Press.

Cohen, D. (2014). Homo Economicus: The (Lost) Prophet of Modern Times. New York, Wiley.

Dekić, M., (2013). Metodološki individualizam i objašnjenje društvenih normi. Godišnjak Fakulteta političkih nauka, 7 (9), 51-64.

From, E. (1980). Zdravo društvo. Beograd, Rad.

Elster, J. (2000).Uvod u društvene znanosti - matice i vijci za objašnjenje složenih društvenih pojava. Zagreb. Hrvatsko sociološko društvo.

Inglehart, R. (1977). The Silent Revolution. Princeton, Princeton University Press.

Gilboa I., Postlewaite A., Samuelson L., Schmeidler, D. (2014). Economic models as analogies. The Economic Journal, 17 (3), 513-533.

Koposov, A.R., Ruchkin, V.V., Eisemann, M., Sidorov I.P. (2005). Alchohol Abuse in Russian delinquent adolescent. Europen Child Adolescent Psychiatry, 14, 254261. 
Kuzmanović, B., Petrović, N. (2007). Struktura preferencija ličnih i društvenih ciljeva srednjoškolaca. Psihologija, 40 (4), 567-585.

Krstić, M. (2015). Teorija racionalnog izbora i objašnjenje društvenih fenomena. Godišnjak političkih nauka, 9 (13), 165-186.

Ljubičić, M. (2010). Psihopatologija maloletnih prestupnika. Sociološki pregled, 44 (2), 205-229.

Maslov A. (1982). Motivacija i ličnost. Nolit, Beograd.

Menkju G. (2007). Principi ekonomije. Beograd, Centar za izdavačku delatnost.

Murray, M. A. (1938). Explorations in Personality. New York, Oxford University Press.

Pallant, J. (2009). SPSS Priručnik za preživljavanje. Beograd, Mikro knjiga.

Rohan, M. J. (2000). A Rose by Any Name? The Values Construct. Personality and Social Psychology Review, 4 (3), 255-277.

Rokeach, M. (1973). The Nature of Human Values. New York, Free Press.

Schwartz, S. (1996). Value Priorities and Behavior: Applying a Theory of Integrated Value Systems. In J. M. Seligman (Ed.), The Ontario Symposium: The Psychology of Values Mahwah (pp.1-24). New Jersey, Lawrence Erlbaum Associates Inc.

Schwartz, S. H., Bilsky, W. (1987). Toward a Psychological Structure of Human Values. Journal of Personality and Social Psychology. 53 (3), 550-562.

Schwartz, S. H., Bilsky, W. (1990). Toward a Psychological Structure of Human Values: Extensions and Cross-Cultural Replications. Journal of Personality and Social Psychology, 58 (5), 878-891.

Simon, H. (1993). Rationality as Process and as Product of Thought. THESIS, 3, 16-38.

Smelser, N., Swedberg, R. (1996). The Handbook of Economic Sociology, Princeton: Princeton University Press.

Shastitko, A. (1998). Models of Human Rational Economic Behaviour. Voprosy Economici, 5, 53-67.

Schwery, R. (1997). Rational Choice Theory: Universal Application or Economic Imperialism? Voprosy Economici. 7, 37-46 .

Sadžakov, S. (2012). Hobbes i problem egoizma. Filozofska istraživanja. 32 (1), 63 77.

Smit, A. (2008). Teorija moralnih osećanja, Podgorica: CID.

Smith, A. (1985). The theory of moral sentiments. In D. D. Raphael (Ed.), Adam Smith (pp. 36-51). Clarendon Press, Oxford.

Sen, A. (2010) Adam Smith and the contemporary world. Erasmus Journal for Philosophy and Economics, 3 (1), 50-67.

Stefanović, Z. (2012). Politička ekonomija globalizacije - modeli kapitalizma i institucionalna ekonomija. Niš, Ekonomski fakultet.

Vasović, M. (1988), "Vrednosti pripadnika neformalnih grupa”. u Joksomović, S. (Urd.), Mladi i neformalne grupe, IIC SSO Srbije, Beograd, pp.174-216. 
Endnotes:

1. The last economic crisis has clearly shown that, for the progress of normal social order, it is necessary to waive the unregulated and unrestricted self-interest. John McCain, the Republican Party candidate for president of the United States 2008 pointed out the greed of Wall Street in his election campaign (Sen, 2010).

2. The objective "subordination" was expressed through the statement "Do not know to express inner feelings which everywhere and always provoke disgust and discomfort". We selected the goal "subordination" as indicator of value rationality, because its content reflects, in the best way, the willingness of subjects to acknowlege and accept the wishes and needs of other people. 